\title{
Physiological Characterization and Emended Description of Methanolobus vulcani
}

\author{
PRIYA C. KADAM ${ }^{1}$ AND DAVID R. BOONE ${ }^{1,2 *}$ \\ Department of Chemistry, Biochemistry and Molecular Biology ${ }^{1}$ and Department of Environmental Science and \\ Engineering, ${ }^{2}$ Oregon Graduate Institute of Science \& Technology, Portland, Oregon 97291-1000
}

\begin{abstract}
Methanolobus vulcani PL-12/M $\mathrm{M}^{\mathrm{T}}$ ( $\mathrm{T}=$ type strain) grew on methylamines and methanol but not on dimethyl sulfide, formate, acetate, or $\mathrm{H}_{2}-\mathrm{CO}_{2}$. The cells grew rapidly at mesophilic temperatures, at neutral pH values (pH 6 to 7.5), and in medium supplemented with 0.1 to $1.2 \mathrm{M} \mathrm{NaCl}$ and $13 \mathrm{mM} \mathrm{Mg}{ }^{2+}$. The cells grew in mineral medium containing biotin and a catabolic substrate, but growth was stimulated by yeast extract and peptones. $M$. vulcani was physiologically similar to Methanolobus tindarius and had a similar 16S rRNA sequence, although the results of DNA-DNA hybridization experiments indicated that these organisms should be considered separate species.
\end{abstract}

The genus Methanolobus is a genus that contains slightly halophilic, methylotrophic methanogens. In 1989, Stetter (16) recognized three species in this genus, Methanolobus tindarius (6), Methanolobus vulcani, and Methanolobus siciliae, but since then Methanolobus siciliae has been transferred to the genus Methanosarcina as Methanosarcina siciliae (10). In addition to Methanolobus vulcani and Methanolobus tindarius, three other species should be classified as members of the genus Methanolobus on the basis of phylogeny as determined by $16 \mathrm{~S}$ rRNA sequences. These species are Methanolobus taylorii (11), Methanolobus bombayensis (5), and Methanohalophilus oregonensis $(2,8)$. However, there has been no formal proposal to transfer the latter species to the genus Methanolobus (2). The results of a comparison of partial sequences of the methylcoenzyme M-methylreductase genes confirmed that this group of five species is a phylogenetically coherent group (15). All five species have been characterized phenotypically $(2,5,6$, 10-12); however, the previously published description of Methanolobus vulcani (16) was rudimentary.

Methanolobus vulcani PL-12/M $\mathrm{M}^{\mathrm{T}}$ (= OCM $\left.157^{\mathrm{T}}\right)(\mathrm{T}=$ type strain) (16) was obtained from the Oregon Collection of Methanogens. The cells of this strain were irregular coccoids with diameters of 1.0 to $1.25 \mu \mathrm{m}$ when the organism was grown in MSHCO2 medium containing $50 \mathrm{mM}$ methanol. MSHCO2 medium was the basal medium used for growth throughout this study (9). The cells lysed when $0.1 \mathrm{~g}$ of sodium dodecyl sulfate per liter was added, indicating that a proteinaceous cell wall was present. Methanolobus vulcani catabolized methanol and trimethylamine. Cultures of this organism did not catabolize $\mathrm{H}_{2}$ either in the presence or in the absence of $50 \mathrm{mM}$ methanol. Cultures also did not grow on formate, acetate, or dimethyl sulfide. The specific growth rate was determined by measuring the amount of methane formed during growth (1). The specific growth rate during exponential growth was determined by using the software package TableCurve (Jandel Scientific, San Rafael, Calif.) to fit data for the total amount of methane accumulated versus time to the Gompertz equation $(4,17)$. The methane produced by the inoculum was included in this calculation (13). Cells were slightly halophilic and grew fastest in the presence of 0.1 to $1.2 \mathrm{M} \mathrm{NaCl}$ (Fig. 1A). Methanolobus vulcani grew fastest at neutral $\mathrm{pH}$ values (Fig. 1B) and did not grow at $\mathrm{pH}$ values greater than 7.5. In contrast, most other species belonging to this genus are alkaliphilic or
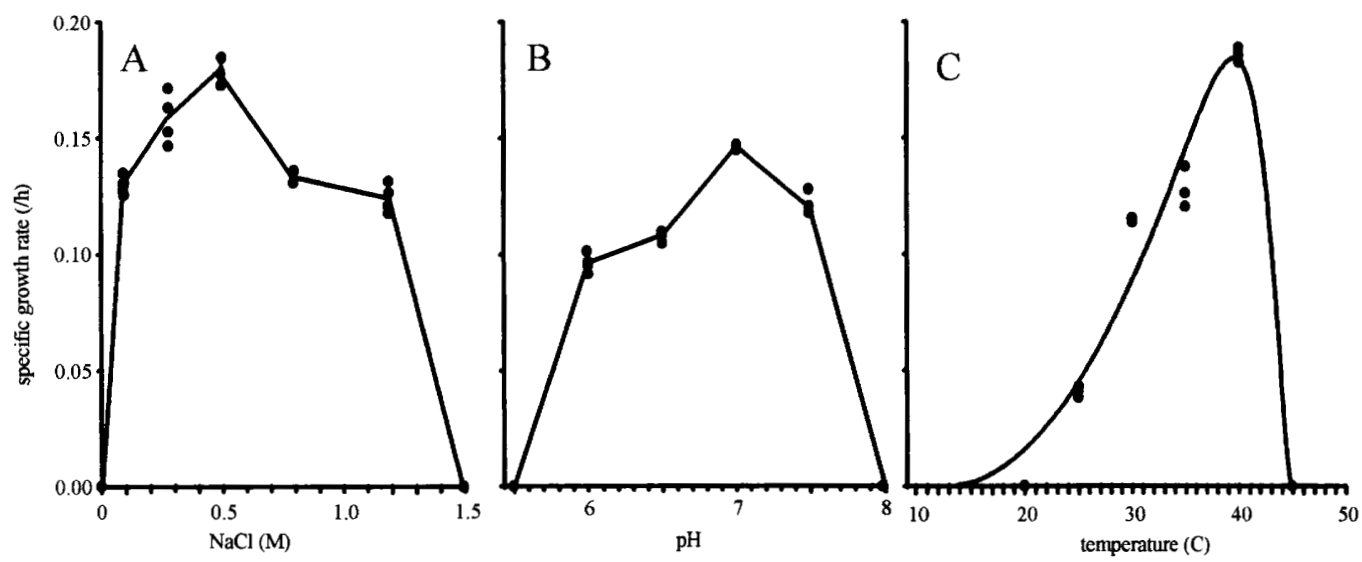

FIG. 1. Effects of salinity (A), pH (B), and temperature (C) on the specific growth rate of Methanolobus vulcani.

\footnotetext{
* Corresponding author. Mailing address: Department of Environmental Science and Engineering, Oregon Graduate Institute, P.O. Box 91000, Portland, OR 97291-1000. Phone: (503) 690-1146. Fax: (503) 690-1273. Electronic mail address: boone@ese.ogi.edu.
} 


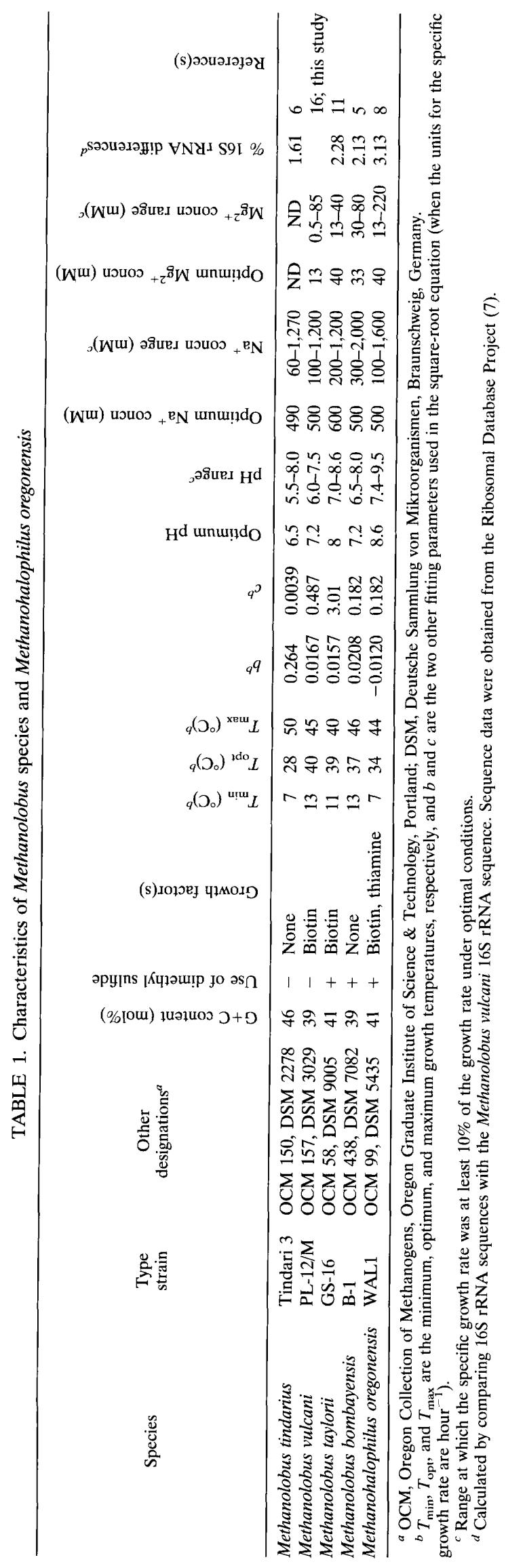

alkali tolerant and grow well at $\mathrm{pH}$ values of more than 7.5 (Table 1).

Specific growth rates at various temperatures were determined (Fig. 1C) and were fitted (by using the TableCurve software) to the square-root equation (14):

$$
\mu=\left\{b\left(T-T_{\min }\right) \cdot c\left[1+\exp \left(T_{\max }-T\right)\right]\right\}^{2},
$$

where $\mu$ is the specific growth rate, $T$ is the temperature, $T_{\min }$ is the minimum temperature for growth, $T_{\max }$ is the maximum temperature for growth, and $b$ and $c$ are constants. The fitted curve obtained for Methanolobus vulcani is shown in Fig. 1C, and the fitting parameters $\left(T_{\min }, T_{\max }, b\right.$, and $\left.c\right)$ are shown in Table 1 . Although the $T_{\min }$ of Methanolobus vulcani was $13^{\circ} \mathrm{C}$, we were not able to detect growth at temperatures even as high as $20^{\circ} \mathrm{C}$ (Fig. 1C). The temperature at which growth is most rapid was determined graphically. We obtained growth rates at various temperatures from previously published descriptions of related species, and we fitted the data obtained in this way to the square-root equation. The results of those analyses are shown in Table 1.

Cells grew well in the presence of $13 \mathrm{mM} \mathrm{Mg}{ }^{2+}$ but grew poorly at $\mathrm{Mg}^{2+}$ concentrations less than $0.5 \mathrm{mM}$ or more than $80 \mathrm{mM}$.

Methanolobus vulcani did not grow in $\mathrm{MSHCO} 2$ mineral medium (MSHCO2 medium lacking organic constituents) supplemented with methanol, but it grew in this medium when biotin was added (specific growth rate, $0.09 \mathrm{~h}^{-1}$ ). Growth was fastest $\left(0.13 \mathrm{~h}^{-1}\right)$ when $2 \mathrm{~g}$ of yeast extract per liter and $2 \mathrm{~g}$ of peptone per liter were added.

Taxonomy. Placement of Methanolobus vulcani in the genus Methanolobus together with Methanolobus tindarius, Methanolobus taylorii, Methanolobus bombayensis, and Methanohalophilus oregonensis is consistent with the phylogenetic relationships and phenotypic characteristics of these organisms (Table 1). The level of differences between the 16S rRNA sequences of Methanolobus tindarius and Methanolobus vulcani is $1.6 \%$ (Table 1); this level of differences is comparable to the levels found between pairs of closely related species or between strains classified together in a single species $(2,3)$. On the basis of the physiological and phylogenetic similarities described above, some workers might consider these two species synonymous. However, the stability of taxonomy should be preserved unless changes are well supported, and we consider these organisms separate species. The low DNA-DNA reassociation value (29\%) between these two species (16) also indicates that these species should remain separate.

Methanolobus vulcani differs more phylogenetically and phenotypically from the other organisms listed in Table 1. The levels of differences between the $16 \mathrm{~S}$ rRNA sequences of Methanolobus vulcani and these species are $2 \%$ or more (Table 1 ). Methanolobus vulcani differs from Methanohalophilus oregonensis and Methanolobus taylorii by lacking alkali tolerance and by not catabolizing dimethyl sulfide. Methanolobus vulcani differs from Methanolobus bombayensis in its ability to grow without high concentrations of divalent cations.

We propose the following emended description of Methanolobus vulcani.

Emended description of Methanolobus vulcani. Methanolobus vulcani Stetter, König, and Thomm 1989 (vul.ca'ni. L. gen. n. vulcani, from Vulcan, the god after whom Vulcano Island [Insula Vulcani] was named). Irregularly coccoid, gram negative, nonmotile. Lysed by $0.1 \mathrm{~g}$ of sodium dodecyl sulfate per liter. Grows on methanol or methylamines, but not on dimethyl sulfide, formate, acetate, or $\mathrm{H}_{2}-\mathrm{CO}_{2}$. Biotin and a catabolic substrate are the only organic compounds required for growth; 
yeast extract and peptone stimulate growth. Grows well at $37^{\circ} \mathrm{C}$, at $\mathrm{pH} 7.2$, and in the presence of $0.5 \mathrm{M} \mathrm{NaCl}$ and $13 \mathrm{mM}$ $\mathrm{Mg}^{2+}$. The guanine-plus-cytosine content of the DNA is 39 mol\%. The type strain is PL-12/M (= OCM 157).

Habitat: sea sediments near Vulcano Island, Italy.

We thank Heide Bard for performing the computer analyses of temperature versus growth rate data.

This work was supported by grant 14-08-001-G2098 from the U.S. Geological Survey.

\section{REFERENCES}

1. Boone, D. R., and W. B. Whitman. 1988. Proposal of minimal standards for describing new taxa of methanogenic bacteria. Int. J. Syst. Bacteriol. 38:212219.

2. Boone, D. R., W. B. Whitman, and P. Rouvière. 1993. Diversity and taxonomy of methanogens, p. 35-80. In J. G. Ferry (ed.), Methanogenesis. Chapman \& Hall, New York.

3. Devereux, R., S. H. He, C. L. Doyle, S. Orkland, D. A. Stahl, J. LeGall, and W. B. Whitman. 1990. Diversity and origin of Desulfovibrio species: phylogenetic definition of a family. J. Bacteriol. 172:3609-3613.

4. Gompertz, B. 1825. On the nature of the function expressive of the law of human mortality, and on a new mode of determining the value of life contingencies. Philos. Trans. R. Soc. London 115:513-585.

5. Kadam, P. C., D. R. Ranade, L. Mandelco, and D. R. Boone. 1994. Isolation and characterization of Methanolobus bombayensis sp. nov., a methylotrophic methanogen that requires high concentrations of divalent cations. Int. J. Syst. Bacteriol. 44:603-607.

6. König, H., and K. O. Stetter. 1982. Isolation and characterization of Methanolobus tindarius, sp. nov., a coccoid methanogen growing only on methanol and methylamines. Zentralbl. Bakteriol. Parasitenkd. Infektionskr. Hyg. Abt. 1 Orig. Reihe C 3:478-490.

7. Larsen, N., J. G. Olsen, B. L. Maidak, M. J. McCaughey, R. Overbeek, T. J.
Macke, T. L. Barsh, and C. R. Woese. 1993. The Ribosomal Database Project. Nucleic Acids Res. 21:3021-3023.

8. Liu, Y., D. R. Boone, and C. Choy. 1990. Methanohalophilus oregonense sp. nov., a methylotrophic methanogen from an alkaline, saline aquifer. Int. J. Syst. Bacteriol. 40:111-116

9. Ni, S., and D. R. Boone. 1991. Isolation and characterization of a dimethyl sulfide-degrading methanogen, Methanolobus siciliae HI350, from an oil well, characterization of $M$. siciliae $\mathrm{T} 4 / \mathrm{M}^{\mathrm{T}}$, and emendation of $M$. siciliae. Int. J. Syst. Bacteriol. 41:410-416.

10. Ni, S., C. R. Woese, H. C. Aldrich, and D. R. Boone. 1994. Transfer of Methanolobus siciliae to the genus Methanosarcina, naming it Methanosarcina siciliae, and emendation of the genus Methanosarcina. Int. J. Syst. Bacteriol. 44:357-359.

11. Oremland, R. S., and D. R. Boone. 1994. Methanolobus taylorii sp. nov., a new methylotrophic estuarine methanogen. Int. J. Syst. Bacteriol. 44:573-575.

12. Oremland, R. S., R. P. Kiene, I. M. Mathrani, M. J. Whiticar, and D. R. Boone. 1989. Description of an estuarine methylotrophic methanogen which grows on dimethyl sulfide. Appl. Environ. Microbiol. 55:994-1002.

13. Powell, G. E. 1983. Interpreting gas kinetics of batch culture. Biotechnol. Lett. 5:437-440.

14. Ratkowski, D. A., R. K. Lowry, T. A. McMeekin, A. N. Stokes, and R. E. Chandler. 1983. Model for bacterial culture growth rate throughout the entire biokinetic temperature range. J. Bacteriol. 154:1222-1226.

15. Springer, E., M. S. Sachs, and D. R. Boone. 1994. Phylogenetic evaluation of methanogens by comparison of the partial sequences of the methylreductase A subunit (mcrA), p. 261. In Abstracts of the 94th General Meeting of the American Society for Microbiology 1994. American Society for Microbiology, Washington, D.C.

16. Stetter, K. O. 1989. Genus II. Methanolobus König and Stetter 1983, 439 VP (effective publication: König and Stetter 1982, 488), p. 2205-2207. In J. T. Staley, M. P. Bryant, N. Pfennig, and J. G. Holt (ed.), Bergey's manual of systematic bacteriology, vol. 3. The Williams \& Wilkins Co., Baltimore.

17. Zwietering, M. H., I. Jongenburger, F. M. Rombouts, and K. van't Riet. 1990. Modeling of the bacterial growth curve. Appl. Environ. Microbiol. 56:1875-1881. 